\title{
The importance of the environment in the transmission of anxiety between parents and their adolescent offspring
}

Article

Accepted Version

Waite, P. and Creswell, C. (2015) The importance of the environment in the transmission of anxiety between parents and their adolescent offspring. Evidence-based mental health, 18 (4). e14. ISSN 1468-960X doi: https://doi.org/10.1136/eb2015-102152 Available at https://centaur.reading.ac.uk/45017/

It is advisable to refer to the publisher's version if you intend to cite from the work. See Guidance on citing.

To link to this article DOI: http://dx.doi.org/10.1136/eb-2015-102152

Publisher: BMJ Publishing

All outputs in CentAUR are protected by Intellectual Property Rights law, including copyright law. Copyright and IPR is retained by the creators or other copyright holders. Terms and conditions for use of this material are defined in the End User Agreement.

$\underline{\text { www.reading.ac.uk/centaur }}$ 
Central Archive at the University of Reading

Reading's research outputs online 
Citation: Eley TC, McAdams TA, Rijsdijk FV, et al. The Intergenerational Transmission of Anxiety: A Children-of-Twins Study. Am J Psychiatry 2015;172:630-7.

Author's declarative title: The importance of the environment in the transmission of anxiety between parents and their adolescent offspring.

\section{Commentary}

\section{What is already known on this topic}

Anxiety disorders can run in families and both genetic and environmental influences have been implicated in this association. Although pediatric twin studies are able to ascertain the proportion of variance in child/adolescent phenotypes due to genetic and environmental influences, to date, they have not been able to specify the extent to which genes and the environment contribute to the transmission of anxiety between parents and their children, ie whether similarities in the amount of anxiety experienced by parents and their offspring are accounted for by sharing genes, living together or both. For this, other genetically sensitive designs are needed. The children-of twins model is one such design and involves adult twin pairs and their offspring. ${ }^{1}$

\section{Methods of the study}

The study by Eley and colleagues drew on data from the Twin and Offspring Study of Sweden. It used a novel Children of Twins design, involving 387 monozygotic (MZ) and 489 dizygotic (DZ) adult same-sex twin pairs, each twin's spouse and one of each of their offspring (aged 11-22 years old). Participants completed measures of anxious personality or symptoms (and neuroticism among a subset). Structural equation modelling was used to explore genetic and environmental transmission from one generation to the next. To examine the influence of living with a parent over and above receiving $50 \%$ of their genes, correlations between adolescent and parent anxiety were compared to equivalent correlations between adolescents and their parent's identical co-twin. In addition, the authors examined differences in the extent that anxiety levels correlated between adolescents and their twin uncle/aunt from $M Z$ and $D Z$ families.

\section{What does this paper add}

- Consistent with existing studies, ${ }^{1}$ comparisons between $M Z$ and DZ adult twins supported genetic influences on anxious personality among adults. For adult twin pairs from MZ families, the correlation for anxiety was 0.51 , whereas in DZ families it was 0.17 .

- However, genetic effects on the intergenerational transmission of anxiety were small ( 0.11 for MZ families and 0.02 for $D Z$ families) and a model reflecting only environmental transmission was the best fit for the data $(p=0.47)$.

- This is the first time it has been shown that the association between parent and offspring anxiety is accounted for by environmental factors over and above the genetic links between family members.

\section{Limitations}

- The cross-sectional design of the study means that we cannot be clear about the direction of environmental mediated effects. One possibility is that parental behaviours, such as expressed anxiety, overprotective or critical parenting, invoke adolescent anxiety. However, it may be equally plausible that adolescent anxiety leads parents to become more anxious themselves and adopt more negative parenting behaviours. Thus, environmental factors, such as parenting behaviours, may influence the development and maintenance of adolescent anxiety symptoms, but may also be a response to the adolescent's anxiety. 
- Ratings of adolescent anxiety included a parent report which may have led to bias.

\section{What next in research}

This research highlights two important questions for future prospective research: 1) can genetic innovation account for the discrepancies in genetic and environmental influences on family aggregation of anxiety in adulthood and adolescence? 2) Does the association between parent and offspring anxiety reflect parental factors (eg anxious, controlling or negative behaviours) influencing and/or being a response to their offspring's anxiety? Treatment research could contribute to resolving this second question through the inclusion of observational assessments of parent-adolescent interactions before and after treatment and the examination of associations between parental behaviours and adolescent treatment outcome. This would establish whether particular parenting behaviours are associated with poorer treatment outcome or whether parental behaviours improve in response to good adolescent outcomes.

\section{Do these results change your practices and why?}

No. Further research to establish causality will be required before committing additional resources to addressing specific environmental factors (such as particular parenting behaviours) within treatment. Indeed, findings from recent prospective studies ${ }^{2,3}$ suggest that high levels of anxiety in adolescents may provoke negative parenting practices and effective treatment of offspring anxiety may improve parenting behaviours. ${ }^{4}$ Nonetheless, the message that genetic factors are not a significant contributor in the transmission of anxiety between parents and adolescents may be reassuring to those concerned that their offspring has inherited anxiety and who believe that this may make symptoms difficult to treat.

\section{Commentator details}

Name: Polly Waite and Cathy Creswell

Affiliation: University of Reading - School of Psychology \& Clinical Language Sciences

City: Reading

Country: UK

\section{References}

1. McAdams TA, Neiderhiser JM, Rijsdijk FV, et al: Accounting for genetic and environmental confounds in associations between parent and child characteristics: a systematic review of children-of-twins studies. Psychol Bull 2014; 140:1138-1173

2. Hale WW, Klimstra TA, Branje SJT, Wijsbroek SAM, Meeus WHJ. Is adolescent generalized anxiety disorder a magnet for negative parental interpersonal behaviors? Depress Anxiety. 2013;30:849-856.

3. Van Zalk N, Kerr M. Shy adolescents' perceptions of parents' psychological control and emotional warmth: Examining bidirectional links. Merrill-Palmer Quart. 2011;57:375-401.

4. Wijsbroek SAM, Hale WW, Raaijmakers QAW, Meeus WHJ. The direction of effects between perceived parental behavioral control and psychological control and adolescents' self-reported GAD and SAD symptoms. Eur Child Adoles Psy. 2011;20:361-371.

\section{Competing interests}

None

\section{Section heading: Causes and risk factors}

Your postal, email and telephone/fax details (not for publication) 


\begin{tabular}{|l|l|}
\hline Title & Dr; Professor \\
\hline Institution & $\begin{array}{l}\text { University of Reading - School of Psychology \& Clinical Language } \\
\text { Sciences }\end{array}$ \\
\hline Postal Address & Whiteknights, Reading, RG6 6AL,UK \\
\hline Email & p.l.waite@reading.ac.uk \\
\hline
\end{tabular}

